\title{
Undertaking Under Oath for a Military Recruit (P.Mich. Inv. 3470)
}

James G. Keenan

Loyola University Chicago, jkeenan@luc.edu

Follow this and additional works at: https://ecommons.luc.edu/classicalstudies_facpubs

Part of the Classics Commons

\section{Recommended Citation}

Keenan, JG. "Undertaking Under Oath for a Military Recruit (P.Mich. Inv. 3470)." Archiv für Papyrusforschung und Verwandte Gebiete 59(2), 2013.

This Article is brought to you for free and open access by the Faculty Publications and Other Works by Department at Loyola eCommons. It has been accepted for inclusion in Classical Studies: Faculty Publications and Other Works by an authorized administrator of Loyola eCommons. For more information, please contact ecommons@luc.edu. (c) $(0) \Theta(\Theta$

This work is licensed under a Creative Commons Attribution-Noncommercial-No Derivative Works 3.0 License. (c) De Gruyter, 2013. 


\title{
Undertaking under Oath for a Military Recruit (P.Mich. Inv. 3470)
}

\author{
James G. Keenan (Chicago)
}

\begin{abstract}
This is an edition of P.Mich. inv. 3470, the lefthand side of a papyrus from Oxyrhynchus dating to AD 350. In it Aurelius Eulogius guarantees the appearance of a recruit named Isak, from the Oxyrhynchite village Episemou, at Alexandria or other required posting.
\end{abstract}

Keywords: army, recruitment, Late Antique Egypt, Oxyrhynchus

P.Mich. inv. 3470

W $7.3 \times \mathrm{H} 26 \mathrm{~cm}$

Oxyrhynchus, AD 350

This is an undertaking under oath with several formal parallels, especially from Oxyrhynchus in the first half of the fourth century. P.Oxy. 50.3576 is the closest match to the present document's format and layout; but see also 54.3746, a tomos synkollêsimos of such documents. The relevant boilerplate had various particular uses, serving sometimes, as in the present case, to assure the presentation of a person or persons to a designated place or before a prescribed authority. Special interest is that the present example concerns a military recruit from the Oxyrhynchite village Episemou in AD 350. By its terms Aurelius Eulogius of Oxyrhynchus swears he has received into custody the recruit, Isak by name, whom he will deliver to Alexandria or other suitable posting, as required, along with the requisite paperwork. There is no clear indication of the unit to which the recruit was destined, but his (possible) Alexandrian assignment (lines 16-17) is an unusual instance of an Egyptian recruit's being sent to serve at a significant distance from his origo; see Anna M. Kaiser, "Rekrutierungspraxis im spätantiken Ägypten," in C. Wolff (ed.), Le métier de soldat dans le monde romain. Actes du cinquième congrès de Lyon organisé les 23-25 septembre 2010 par l'Université Jean Moulin Lyon 3. Collection Études et de Recherches sur l'Occident Romain (Lyon, 2012): 99-120 + Bibliographie. Dr. Kaiser also points (e-mail, July 11, 2013) to P.Oxy. 9.1190 (AD 347, recruits sent to Egyptian Babylon) and W.Chr. 469 (= Sel.Pap. II 228, after AD 380-382, recruits sent to Antioch) as exceptions to this practice.

The present document conforms to A.H.M. Jones's description of military conscription in the fourth century (Later Roman Empire 614-619, esp. 615-616): levies were made city by city, but burdens fell principally upon the rural population. It is a nice complement to W.Chr. 466 and 467, both fourth century. In the former, the villagers of Toou of the Herakleopolite Nome pay 30 solidi to the

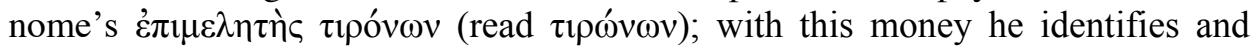
purchases the services of a recruit from the same village. The latter is a sworn 
guarantee by the villagers of Pesla of the Hermopolite Nome for a recruit from their own village. The former is therefore perhaps initially concerned with a payment associated with the aurum tironicum; the latter, like the present document, is directly concerned with a recruit "en chair et en os." Cf. P.Oxy. 45.3261 (AD 324), also concerned with flesh-and-blood recruits.

On recruitment in the fourth century and the debate about putative reforms dating to the 370 s, see J.-M. Carrié, "Le système de recrutement des armées romaines de Dioclétien aux Valentiniens," (in) Y. Le Bohec and C. Wolff (eds.), L'armée romaine de Dioclétien à Valentinien $I^{\text {er }}$. Actes du congrès de Lyon (12-13 septembre 2002 (Lyon, 2004) (Coll. du Centre d'Études Romaines et GalloRomaines 26): 371-387, for whom Diocletian remains the great innovator (383 on P.Oxy. 3261; 384-385 on W.Chr. 466). He is arguing against C. Zuckerman, "Two Reforms of the 370s: Recruiting Soldiers and Senators in the Divided Empire," Revue des études byzantines 56 (1998) 79-139, another valuable contribution on this topic, especially, for purposes of the Michigan papyrus, 91-97.

The present undertaking preserves: consular year date (line 1-[2]); address (lines 3-8); agreement on oath (lines 8-20), identification of the party to be delivered (lines 21-23), consular date, abbreviated but presumably adding month and day (line 24), and the oath-taker's subscription (lines 25-28). Only the left half of the papyrus survives. There are margins at top, left, and bottom. The top margin, discounting the oversized upsilon at the start, measures $1 \mathrm{~cm}$. (but see the marginal intrusion described below). The left margin is fairly evenly maintained at ca. $1.5 \mathrm{~cm}$. The bottom margin is likewise ca. $1.5 \mathrm{~cm}$. but for the descender of rho

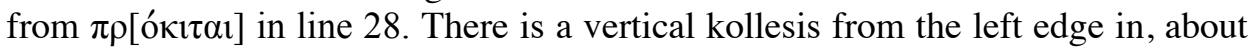
$2 \mathrm{~cm}$. wide, with a ragged right edge.

Despite the document's discrete segments, in one case (between lines 23 and 24) set off by a vertical space, in another (between lines 24 and 25) set off by a paragraphus, the hand appears to be the same throughout, a cursive of medium size that runs with the fibers. This must therefore be a copy, not the original document, a conclusion that may be supported by traces of tiny writing in the top margin where, with the eye of faith, alpha and nu may perhaps be discerned, sug-

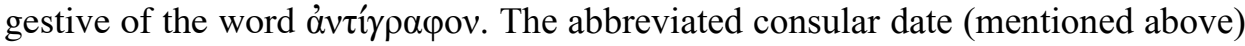
and the short form of the oath formula (lines 9-10n.) also support this conclusion.

Where writing survives, the writer shows a preference for iota over epsilon-iota (e.g., lines 3, 16-17, 26, but see 1, 24) and in one case (lines 26-27) omicron over omega. I have nevertheless retained standard spelling in restorations except for line 28 where the writer's proclivity seemed too obvious to ignore.

The verso is blank.

According to APIS records, this papyrus was purchased from Maurice Nahman in 1925. It came to Michigan in October 1926 "as a gift of Oscar Weber and Richard H. Webber (of Detroit)." According to John G. Pedley, The Life and Works of Francis Willey Kelsey: Archaeology, Antiquity, and the Arts (Ann Arbor, 2012), the two men were brothers; he indexes them under "Webber." Kelsey's 


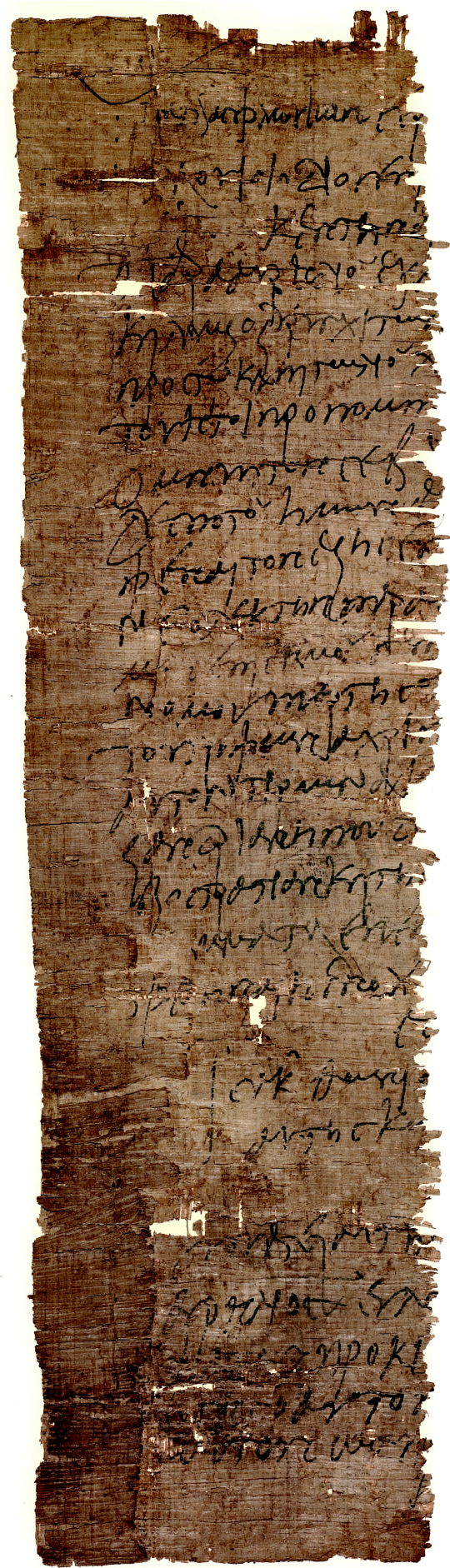

P.Mich. inv. 3470: Undertaking under Oath for a Military Recruit 
papers in the Bentley Historical Library at the University of Michigan, examined by Todd M. Hickey in June 2013, prove Pedley is correct. Working through the amous "papyrus cartel", Kelsey nominally acquired the lots to which P.Mich. inv. 3470 belongs, 350 documents in all, in late 1925. The Webbers pledged money to cover the cost, at $\$ 1250$ apiece (the two checks were sent from Detroit to Ann Arbor, April 9, 1926). The papyri, originating from Nahman's collection in Cairo, were being held for Michigan at the British Museum, which was serving as gobetween in transactions with Nahman. Both Kenyon and Bell, the latter of whom presented Kelsey with a detailed evaluation, judged the lots disappointing. In any event, Kelsey brought the papyri to Ann Arbor from London in October 1926. Although both brothers were donors, Kelsey's correspondence concerning this transaction is with Oscar Webber (sic, correctly) only.

The image is digitally reproduced with the permission of the Papyrology Collection, Graduate Library, University of Michigan. I am grateful to C. Michael Sampson and Todd M. Hickey: to the former, especially for his close readings of the article in its manuscript form; to the latter, especially for the information supplied in the preceding paragraph. Important refinements are owed to members of the "papyrology group" that met in Hatcher Library 807 on June 19, 2013, especially Graham Claytor, Drew Stimson, and Arthur Verhoogt. Remaining defects are mine alone.

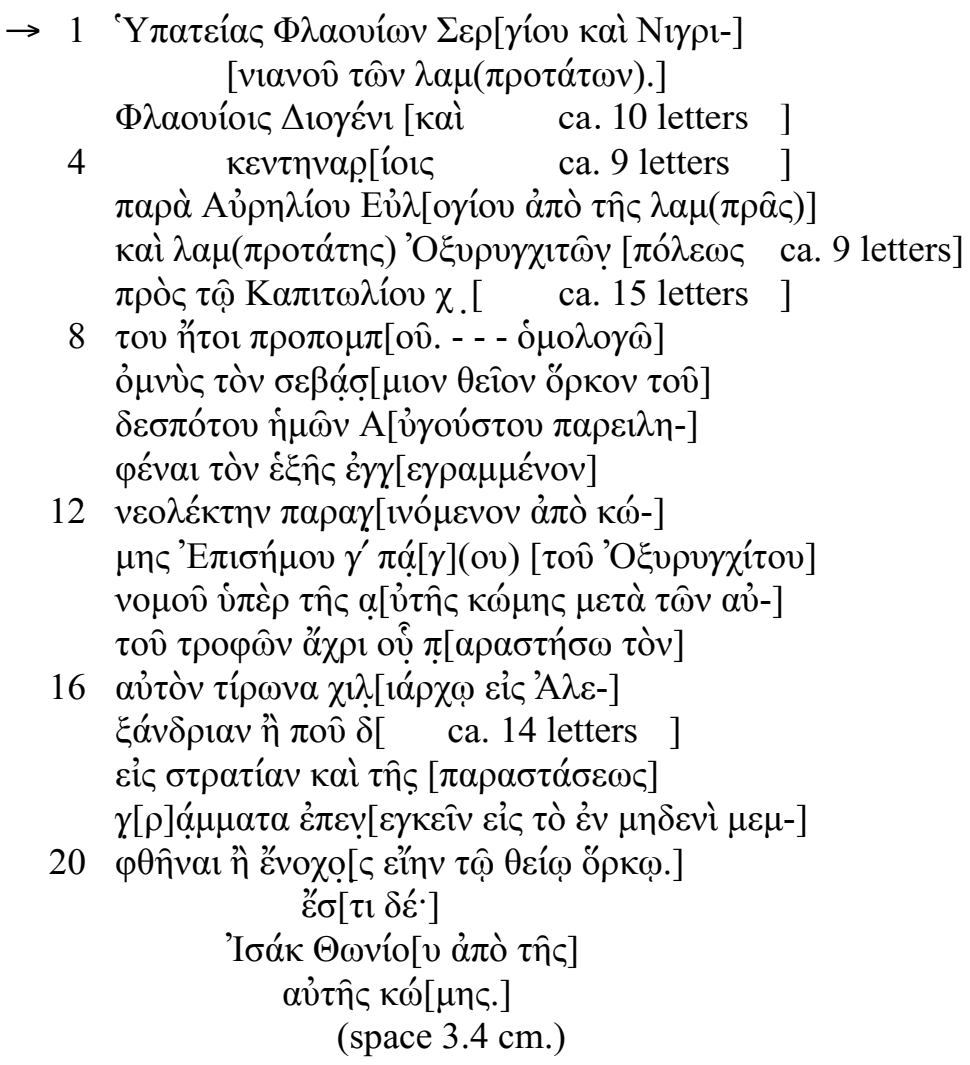




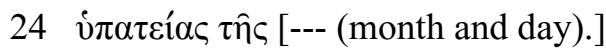

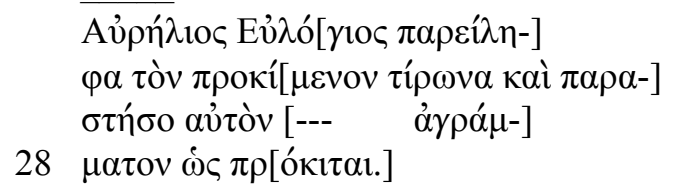

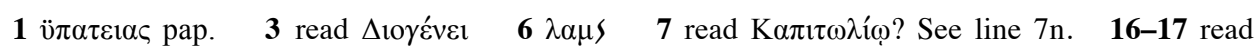

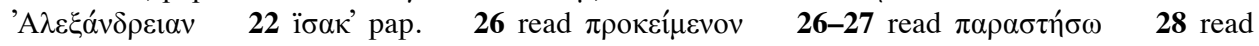

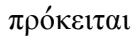

\section{Translation}

In the consulship of Flavii Ser[gius and Nigrinianus clarissimi.]

To Flavii Diogenes [and NN], centenarii ..., from Aurelius Eul[ogius from the brilliant] and most brilliant [city of] Oxyrhynchites ... at the ... of the Capitolium, ... or escort. [I agree] swearing the sacr[ed divine oath] of our lord A[ugustus that I have recei]ved the recruit in[scribed] immediately below, com[ing from the vil]lage Episemou of the $3^{\text {rd }} \mathrm{pa}[\mathrm{g}]$ (us) [of the Oxyrhynchite] nome, on behalf of the $\mathrm{s}$ [ame village together with] his provisions until [I] $\mathrm{p}$ [resent the] said recruit to the trib[une at Ale]xandria or wherever ... for military service; and for [his presentation] I have sub[mitted] a written document [so that no] fault [be found in any respect], or [may I be] liable [to the divine oath.]

He is:

Isak son of Thoni(o)s [from the] same vil[lage.]

Consulship the [aforementioned, (month and day).]

I, Aurelius Eulo[gius, have present]ed the afore[mentioned recruit and I shall pre]sent him, [... illiter]ate, as afor[ementioned].

I, Aurelius Eulo[gius, have present]ed the afore[mentioned recruit and I shall pre]sent him, [... illiter]ate, as afor[ementioned].

1-3 Under the initial upsilon's bowl, enormous in size, are three dots, each apparently serving as guidepoints for the vertical spacing of the opening lines. No writing survives after the second dot because (I presume) the second line of the consular date was indented, as in P.Oxy. 50.3576.1-2, cf. P.Oxy.10.1261.1-2. The writing of line 2 must therefore have been tiny (vertically). It is impossible to tell where to place the break between lines 1 and 2 . The writer has no qualms about dividing words, never mistakenly, between lines; see the transitions at lines 7-8, 10-11, 12-13, 14-15 (apparently), 16-17, and 19-20. There seems not to be sufficient space for writing $\lambda \alpha \mu \pi \rho \tau^{\prime} \alpha \dot{\tau} \omega v$ in full, cf. lines 5-6 and n. For the two consuls, not known in Egypt for the first two months of the year (at least), see R.S. Bagnall and K.A. Worp, The Chronological Systems of Byzantine Egypt ${ }^{2}$ (Leiden, 2004) 186, R.S. Bagnall, A. Cameron, S.R. Schwartz, and K.A. Worp, Consuls of the Later Roman Empire (Atlanta, GA, 1987) 235. 
3-4 centenarii = centuriones $($ Vegetius 2.13). See S. Daris, Il lessico latino nel greco d'Egitto $^{2}$ (Barcelona, 1991) 53 for references. In line 4 the name of the military unit presumably follows, though part or all of this space may have been left blank.

5 Eủ $\lambda$ [oyíov: for Eulogius, see line 25. There is nonetheless a significant descending stroke starting from the v-point of the upsilon, an apparent stray, without evident purpose. Both restorations thus seem unavoidable.

5-6 For $\lambda \alpha \mu$ s twice as abbreviation, see P.Oxy. 50.3576.5 and [6], 54.3746.50.

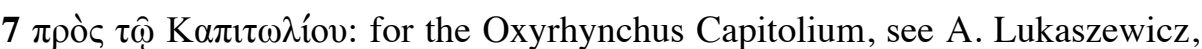
Les édifices publics dans les villes de l'Égypte romaine (Warsaw, 1986) 55, 173174, and J. Krüger, Oxyrhynchos in der Kaiserzeit. Studien zur Topographie und Literaturrezeption (Frankfurt am Main, 1990) 104 (no. 24). Whether at this late date it retained its cultic functions is unascertainable: cf. AnneMarie Luijendijk, Greetings in the Lord: Early Christians and the Oxyrhynchus Papyri (Cambridge, MA, 2008) 15-16. See P.Oxy. 54.3757.3 (and line 3n.) and 3758.156, for the Capitolium as a setting for court proceedings in AD 325. Both citations have $\pi \rho \grave{c} \varsigma$

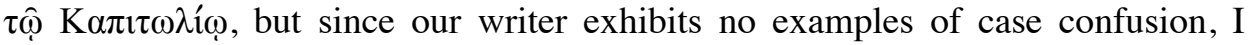
assume here that the genitive case is correct and the writer is continuing his description of Eulogius' positions, carrying over from line 6. Eulogius may therefore have been in charge of a part of the Capitolium that began with chi. There are no parallels.

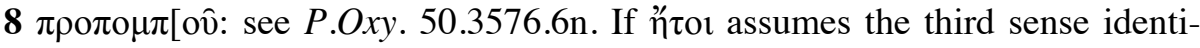
fied by P.J. Sijpesteijn, "The Meanings of "̈ $\tau$ or in the Papyri," ZPE 90 (1992) 241-250 at 245-246, i.e., "and especially," the word that begins on line 7 and carries over to 8 provides the genus of which $\pi \rho 0 \pi \circ \mu \pi$ [ov gives a species. No such pairing of terms is recorded in the papyri, but the use of the verb $\varepsilon \gamma \gamma v \alpha$ ó in combination with $\pi \alpha \rho^{\prime} \sigma \tau \eta \mu \mathrm{in}$ analogous circumstances (e.g., P.Abinn. 61.5-6, 9,

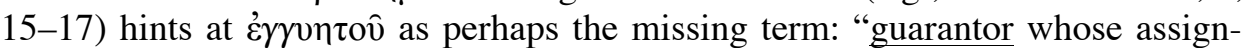
ment is to serve as recruit escort." But there are other likely options, including

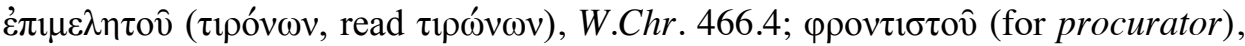
based on the Latin legal texts cited by Jones, Later Roman Empire 615-616 with

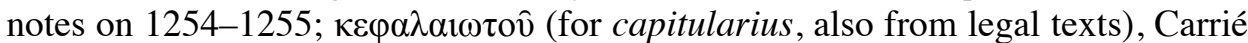

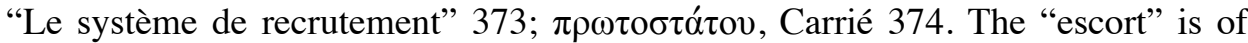
course Eulogius and the word $\pi \rho \circ \pi \circ \mu \pi[0 \hat{v}$ marks the end of the document's address. A blank space may follow; or there may be room for $\chi \alpha$ ípeıv, but this is not indicated by the cited parallels.

9-10 The emperor is Constantius II. For the restorations, see pattern Xc in K.A. Worp, "Oath Formulas with Imperial Titulature in Byzantine Greek Papyri," ZPE 45 (1982) 199-223, at 204, four examples, cf. P.Mich. 20, Index 4 on p. 192, fourteen examples, all Oxyrhynchite.

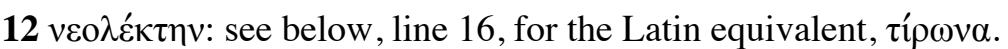


$\pi \alpha \rho \alpha \gamma$ [ivó $\mu \varepsilon v o v$ : the best of the lexically available terms (aorist $\pi \alpha \rho \alpha \gamma \varepsilon v o ́ \mu \varepsilon v o v$ is also theoretically possible): H. Braunert, Die Binnenwanderung. Studien zur Sozialgeschichte Ägyptens in der Ptolemäer- und Kaiserzeit (Bonn, 1964) 384385, Index 5, "Verzeichnis der Terminologie zur Binnenwanderung."

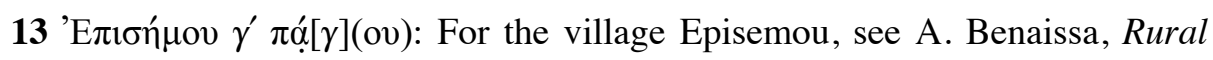
Settlements of the Oxyrhynchite Nome: A Papyrological Survey,Version 2.0 (May 2012), Trismegistos Online Publications IV, 68-70. Pagus identification is expected next: P.Oxy. 12.1425.6, 54.3746.25. Gamma (for $3^{\text {rd }}$ ) and the pi that follows are joined by a ligature that rises in its middle to a little loop, which must serve as the number marker for gamma.

14 Because of $\tau \hat{\imath} \varsigma \alpha[$ ป $\tau \hat{\eta} \varsigma$ repetition of the village name is unnecessary: e.g., P.Oxy. 12.1425.10-12.

14-15 $\mu \varepsilon \tau \grave{\alpha} \tau \hat{\omega} v \alpha \hat{v}] \mid \tau o \hat{~} \tau \rho \circ \varphi \hat{v} v$ : The term here suggests food, but could also include clothing, equipment, and travel expenses - all part of his "draft allowance." See Zuckerman, "Two Reforms of the 370s," esp. 94-97. Considering the length of the supplement which extends line 14 up to 31 letters, one could assume that $\alpha\left[\hat{v} \tau \hat{\eta} \varsigma\right.$ was abbreviated $\left(\alpha \cdot\left[v^{\tau}\right)\right.$, but since line 19 has 3 more letters, this seems not really necessary.

$16 \chi 1 \lambda[$ [1óp $\chi \omega:$ : common term for commander of a military unit in the Ptolemaic and Roman periods; its latest attestation as such seems to be from the beginning of the fourth century ( $S B$ 24.16000). Its function in the later period seems to have been assumed by the Latin loanword tribunus. See Daris (lines 3-4n.) 112.

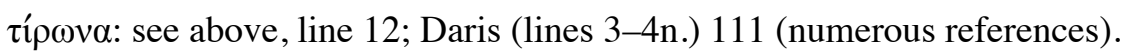

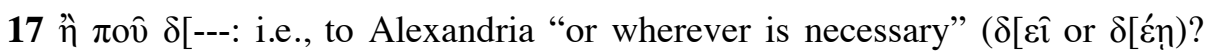
The expression is unparalleled. What seems intended is an indirect question con-

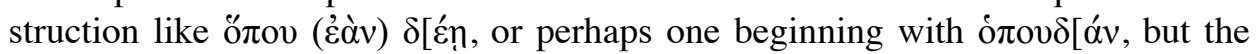
hoped-for omicron is nowhere to be seen.

18-20 A common formula, but with variations, sometimes in restoration: P.Oxy. 10.1261.10-12; 43.3127.12-13; 50.3576.13-15; 54.3746.10-13, 35-37, 60-62, cf. 60.4086.10. The restoration in line 19, at 22 letters, is the longest of those proposed for the entire text, but one where the forumla eic $\tau$ ò $\dot{\varepsilon} v \mu \eta \delta \varepsilon v i$ $\mu \varepsilon \mu \varphi \theta \hat{\eta} v \alpha \mathrm{l}$ is at its most strict (numerous additional examples in the Navigator of www.papyri.info). Meanwhile, the supplement in line 18, at 11 letters, is among

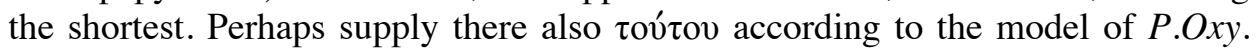
50.3576.13.

21 The line is just about perfectly centered; such alignment would be ruined by restoration of the recruit's status designation, whether Aurelius (W.Chr. 467; cf. P.Oxy. 12.1425.10-12, 1426.15-17, though not from a military context) or Flavius (W.Chr. 466).

22 Iota in 'Iбók is written enormously, its lower extension occupying also the beginning of line 23. Of interest is the combination of this presumably Christian 
(because Old Testament) name with a "pagan," and typically Oxyrhynchite, patronymic. For this naming trend at this time, see R.S. Bagnall, "Religious Conversion and Onomastic Change in Early Byzantine Egypt," BASP 19 (1982) 105-125 = Bagnall, Later Roman Egypt: Society, Religion, Economy and Administration (Aldershot, Hampshire/Burlington, VT, 2003): chapter VIII.

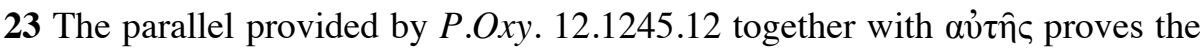
village name in line 13 does not require repetition here. See above, line 14 and note.

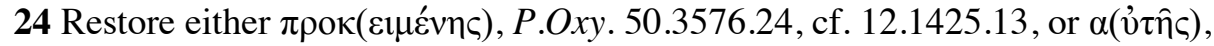
P.Oxy. 54.3746.38 and 63.

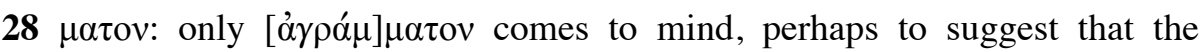
recruit in his illiteracy was not "officer material." See W.Chr. 466.15-16, where the recruit is similarly noted to be illiterate. 
Copyright of Archiv für Papyrusforschung und Verwandte Gebiete is the property of De Gruyter and its content may not be copied or emailed to multiple sites or posted to a listserv without the copyright holder's express written permission. However, users may print, download, or email articles for individual use. 